\title{
Features of Digitalization of the Economy in the Socio- Economic Development of the Far Eastern Federal District
}

\author{
Luciena E. Piunko*, Elena V. Tolkacheva \\ Department of mathematical methods and information technologies, Far-East Institute of management, branch of the \\ Russian Presidential Academy of National Economy and Public Administration (hereinafter RANEPA), Khabarovsk \\ 680000, Russia \\ *Corresponding author. Email: lusiena_03@mail.ru
}

\begin{abstract}
The article deals with theoretical and statistical assessments of the digitalization of the economy in Russia as a whole and in the Far Eastern Federal District. Calculations of growth rates of objective indicators of the digital economy at the beginning of 2018 are given, as well as an analysis of sociological issues in Russia, concerning aspects of the development of digitalization in the country and the psychological readiness of the population to integrate digitalization into their daily lives. The authors present the results of the analysis of the main trends in the implementation of the provisions of the national program "Digital economy of the Russian Federation". A comparative analysis of the positions held by the Far Eastern Federal District on a number of criteria for digitalization of the economy among the subjects of the Russian Federation at the time of the start of the regional project "Digital economy" is given. The article reveals the main difficulties of implementing the national project "national program " Digital economy" in Russia as a whole, and in the Far Eastern Federal District.
\end{abstract}

Keywords: Digital economy, subject of the Russian Federation, socio-economic environment of the region,

information society

\section{INTRODUCTION}

To implement the provisions currently enshrined in the Russian legislation on the development of the digital economy, the country must solve its own space targets regarding personnel policy in the digital economy (training of high-quality specialists in the information and technology sphere), as well as train the economically active population to use modern information and communication technologies and digital technologies not only in their professional activities, but also at home, in improving their educational level, in solving their personal tasks, that is, to involve the population in the use of digital services everywhere. It is important to find ways and techniques to motivate the population to integrate digitalization objects in their daily life and professional activities (using the Internet of things, replacing already familiar applications with cloud services, widespread introduction of artificial intelligence in production systems, etc.), because this solution provides mechanisms for economic growth and export of digital economy technologies to other regions.

\subsection{Aspects of professional education in the digitalization circuit}

Given the fact that the professional education system, in the current conditions in Russia, hardly manages to adjust its educational programs to the dynamic requirements for training specialists in the field of digital economy, there is a disconnect between the actions of modern enterprises and educational institutions to train specialists in the field of digital economy, who have the necessary skills and competencies. There are new professions and new requirements for the competence of specialists in the digital economy. In order to develop the digital economy and reduce the social tension in society that domestic and foreign researchers talk about, it is necessary that the rare and necessary professions in the digital economy today are not difficult to access. It is necessary for the modern educational environment to promote retraining of a wide part of the population, or for citizens to obtain additional professions in the field of digitalization. This is especially true for the part of the population that has education in disappearing specialties and areas. thus, today we need a close coordinated work of the Executive power and educational institutions to develop new professional standards and educational programs for training the required specialists in the field of digital economy, updating the material base and training tools for the implementation of educational programs in this area. The government of the Russian Federation and the governments of the constituent entities of the Russian Federation today understand the semantic content of all the above-described challenges, and 
in advance try to solve the issues of integration of digitalization in society not only at the legislative level, but also by developing detailed programs for the development of a digital society in Russia. However, in the development of development programs, the actions of ministries and departments do not always correlate with each other, especially at the level of subjects of the Russian Federation.

\subsubsection{Research issues of regional stages of digital economy development in Russia}

Domestic researchers, in our opinion, do not pay enough attention to regional aspects of the development of the digital economy in Russia, and in particular, on the territory of the far Eastern region (Zubarev A. E., Zhadan I. E., Sudarushkina I. V., Stefanova N. A., Chernova V. Yu., Shvab K. [3, 4, 5, 6, 7]). At the same time, regional digital economy projects are in many ways the main mechanism for the successful implementation of the new national program for the development of the digital economy, approved in 2018. This is largely due to the fact that the decree of the Government of the Russian Federation dated 28.07.2017 No. 1632-R "on approval of the program "Digital economy of the Russian Federation" has lost its force. Following a meeting of the Presidium of the presidential Council for strategic development and national projects on December 24, 2018, the passport of the national program "Digital economy of the Russian Federation" was approved [1].

\subsubsection{Aspects of government regulation of digital economy development in Russia}

Despite all the difficulties described above, the legal framework of the Russian Federation outlines in sufficient detail the directions of development of the digital economy. Thus, according to the Decree of the President of the Russian Federation dated 07.05.2018 No. 204, the Government of the Russian Federation, when implementing the national program "Digital economy of the Russian Federation" in conjunction with the state authorities of the Russian Federation, must ensure that in 2024:

(a) achieving the following goals and targets:

- an increase in domestic spending on the development of the digital economy from all sources (as a share of the country's gross domestic product) by at least three times compared to 2017.;

- creating a stable and secure information and telecommunications infrastructure for high-speed transmission, processing and storage of large amounts of data, accessible to all organizations and households;

- use of primarily domestic software by government agencies, local governments, and organizations;

b) solving the following tasks:

- creation of a system of legal regulation of the digital economy based on a flexible approach in each area, as well as the introduction of civil turnover based on digital technologies;

- creation of a global competitive infrastructure for data transmission, processing and storage, mainly based on domestic developments;

- ensuring the training of highly qualified personnel for the digital economy;

- ensuring information security based on domestic developments in the transmission, processing and storage of data that guarantees the protection of the interests of individuals, businesses and the state;

- creation of end-to-end digital technologies mainly based on domestic developments;

- introduction of digital technologies and platform solutions in the areas of public administration and public services, including in the interests of the population and small and medium-sized businesses, including individual entrepreneurs;

- transformation of priority sectors of the economy and social sphere, including health, education, industry, agriculture, construction, urban development, transport and energy infrastructure, financial services, through the introduction of digital technologies and platform solutions; - creation of a comprehensive system for financing projects for the development and (or) implementation of digital technologies and platform solutions, including venture financing and other development institutions;

- development and implementation of a national mechanism for implementing the coordinated policy of the member States of the Eurasian economic Union in the implementation of plans for the development of the digital economy [2].

The goals themselves already include the development and modernization of domestic technologies in the field of Informatization, information systems, "Big Data" technologies, the Internet of things, and domestic software (including CASE systems, ERP systems, CRM systems, and so on).

The project structure is represented by six levels:

1. Regulatory regulation of the digital environment;

2. Information infrastructure;

3. Human resources for the digital economy;

4. Information security;

5. Digital technology;

6. Digital public administration [1].

Thus, the legislator has moved to a more thorough detailing of the goals of the national project "Digital economy of the Russian Federation". the specific structure and semantic content of the vectors of its development have already been outlined from the streamlined wording.

It should be noted that the results outlined in the project "Regulatory regulation of the digital environment" will contribute to the implementation of national interests in the digital economy, such as ensuring the lawful use of personal data, information originating from industrial, transport, communications infrastructure, as well as data obtained from state information systems [2].

The results outlined in the Information infrastructure project suggest creating conditions for the implementation of such national interests in the digital economy as ensuring the 
functioning of social, economic and managerial systems using the Russian segment of the Internet [2].

The project "Information security" contributes to the implementation of national interests in the field of information society development such as:

- strengthening the Russian economy, including those sectors in which business development using information and communication technologies will provide competitive advantages to Russian organizations, ensure production efficiency and increase labor productivity;

- increasing the volume of non-primary Russian exports, primarily of goods and services that are in demand among foreign consumers, through the use of new technologies;

- increasing the competitiveness of Russian high-tech organizations in the international market;

- ensuring the technological independence and security of the infrastructure used to sell goods and provide services to Russian citizens and organizations [1].

The Digital technologies project will help create new markets based on the use of information and communication technologies, and ensure leadership in these markets through the effective use of knowledge and the development of the Russian ecosystem of the digital economy, as outlined in the Strategy [1].

The project "Digital governance" contributes to the task of shaping a new technological basis for the development of economy and social sphere development of technology of electronic interaction between citizens, organizations, state bodies, bodies of local self-government, while maintaining the possibility of interaction of citizens with these organizations and bodies without the use of information technology and application in the state bodies of the Russian Federation new technologies for improving the quality of public management [1].

\subsection{Quantitative and qualitative assessment of the implementation of the tasks of the passport of the national program " Digital economy of the Russian Federation"}

Accordingly, the implementation of the tasks of the passport of the national program will contribute to the implementation of the Decree of the President of the Russian Federation dated may 7, 2018 No. 204 "on national goals and strategic development tasks of the Russian Federation for the period up to 2024" [2].

According to the authors, for a detailed assessment of the quantity and quality of events, including the assessment of their economic efficiency. it is necessary to monitor digitalization targets at the Federal level within the framework of the national project. To do this, you need to define a system of indicators and measure them by period. The Federal state statistics service has been monitoring the development of the information society in the Russian Federation since 2010 in the following sections: 1. Factors of information society development; 2 . Using information and communication technologies (ICT) for development [8, 14]. However, in the statistical observations of Rosstat and their reports, there are no values of the completed targets of the national program, i.e. the structure of indicators that assess the targets of the national program "Digital economy" has not been developed. This circumstance in itself needs to be corrected, and Rosstat and the Ministry of digital development, communications and mass communications of the Russian Federation are currently working in this direction.

Based on the processed data of Rosstat, the Government of the Russian Federation indicates additional indicators of the digital economy project: the share of households with broadband Internet access (percent); the share of the Russian Federation in the global volume of data storage and processing services (percent); the presence of reference data processing centers in Federal districts (number); the average downtime of state information systems as a result of computer attacks (hours); the average downtime of state information systems as a result of computer attacks (hours), etc. But, with all this, the indicators of the digital economy collected and processed by Rosstat do not coincide in their meaning and name with the target indicators recorded in the passport of the national project of the digital economy of the Russian Federation.

If we take into account sociological surveys in Russia as a whole about the readiness of the population to use information technologies in everyday life, the following is observed:

1. According to the Levada center, $13 \%$ of the survey participants switched to contactless payments by mobile phone (ApplePay, GooglePay, SamsungPay, etc.); $11 \%$ of respondents use money transfer to the seller by phone number, and 6\% use e-wallets (QIWI, Yandex.Money", WebMoney) [9].

2. Readiness of entrepreneurs to label goods: the vast majority of respondents know about the introduction of labeling, or at least have heard about this project $(89 \%$ of all respondents). At the same time, the largest percentage of those who are well aware of labeling is among entrepreneurs in the tobacco trade (49\% of all respondents belonging to this trade) and in the non-specialized trade, where shoes and/or tobacco products are sold in addition to everyday goods (46\%), while among entrepreneurs working in the Shoe trade, the share of those who are well aware of the introduction of labeling is $27 \%$ [10].

3 . The survey showed that in recent years, the number of users of all ages who access the world wide web daily has been growing ( $49 \%$ in $2017,44 \%$ in 2016 , and $41 \%$ in 2015) [11]. At the same time, there is a slight decrease in the number of respondents who indicated that they go online several times a week (12\% vs. $16 \%$ a year earlier), once a week or less (7\% vs. $9 \%$ ). The most active user category is young people aged 18-24. $90 \%$ of young people use the Internet every day. This figure is $83 \%$ among citizens aged $25-39,60 \%$ in the $40-54$ category, and $25 \%$ among $55+$ citizens [12].

Exploring the development of information infrastructure in the Far Eastern Federal District, focusing on the region of interest for the authors note that in the Far Eastern Federal District implementation of the national programme "Digital economy of the Russian Federation" introduced by the 
indicators of digitalization development in the region is presented in table 1 and figure 1 (for the period of 2017). regional projects", approved at the level of subjects Far Eastern Federal District [13]. Information on individual

Table 1 Indicators of information and communication (IIC) technologies of the population of the Far Eastern Federal District in 2017 (as a percentage)

\begin{tabular}{|l|c|c|c|c|c|c|c|c|c|c|}
\hline \multicolumn{1}{|c|}{ Population } & $\begin{array}{c}\text { Republic } \\
\text { of Sakha } \\
\text { (Yakutia) }\end{array}$ & $\begin{array}{c}\text { TRANS- } \\
\text { Baikal } \\
\text { territory }\end{array}$ & $\begin{array}{c}\text { Kamcha } \\
\text { tka }\end{array}$ & $\begin{array}{c}\text { Primory } \\
\mathbf{e} \\
\text { territory }\end{array}$ & $\begin{array}{c}\text { Khabarov } \\
\text { sk } \\
\text { territory }\end{array}$ & $\begin{array}{c}\text { Amur } \\
\text { region }\end{array}$ & $\begin{array}{c}\text { Magad } \\
\text { an } \\
\text { region }\end{array}$ & $\begin{array}{c}\text { Jewish } \\
\text { in } \\
\text { region }\end{array}$ & $\begin{array}{c}\text { Chukotka } \\
\text { Autonomous } \\
\text { region } \\
\text { Autonomou } \\
\text { s district }\end{array}$ \\
\hline $\begin{array}{l}\text { Personal computers in } \\
\text { households }\end{array}$ & 67,3 & 66,3 & 68,6 & 76,5 & 71,9 & 72,4 & 78,8 & 74,9 & 68,8 & 78,6 \\
\hline Mobile Internet in households & 74,8 & 46,9 & 58,8 & 60,2 & 60,9 & 55,2 & 79,3 & 66,7 & 58,6 & 45,0 \\
\hline $\begin{array}{l}\text { Broadband Internet in } \\
\text { households }\end{array}$ & 76,6 & 61,5 & 70,0 & 76,2 & 73,2 & 70,8 & 59,6 & 74,7 & 72,2 & 33,8 \\
\hline $\begin{array}{l}\text { Internet user } \\
\text { They go online every day }\end{array}$ & 85,8 & 76,6 & 82,3 & 83,5 & 82,1 & 83,4 & 86,4 & 77,6 & 77,0 & 91,7 \\
\hline $\begin{array}{l}\text { Access the Internet from mobile } \\
\text { devices }\end{array}$ & 78,1 & 48,8 & 71,9 & 66,5 & 65,0 & 58,1 & 64,3 & 62,8 & 44,8 & 67,9 \\
\hline Make purchases online & 31,2 & 17,2 & 43,8 & 28,9 & 28,8 & 18,4 & 30,6 & 30,9 & 24,2 & 31,8 \\
\hline $\begin{array}{l}\text { Receive electronic public } \\
\text { services }\end{array}$ & 46,2 & 37,8 & 54,3 & 64,8 & 49,5 & 67,1 & 37,8 & 57,2 & 36,4 & 19,2 \\
\hline
\end{tabular}

a Official portal "Ministry of digital development , communications and mass communications of the Russian Federation" [Electronic resource] / access Mode: https://digital.gov.ru/ru/pages/statistika-otrasli/

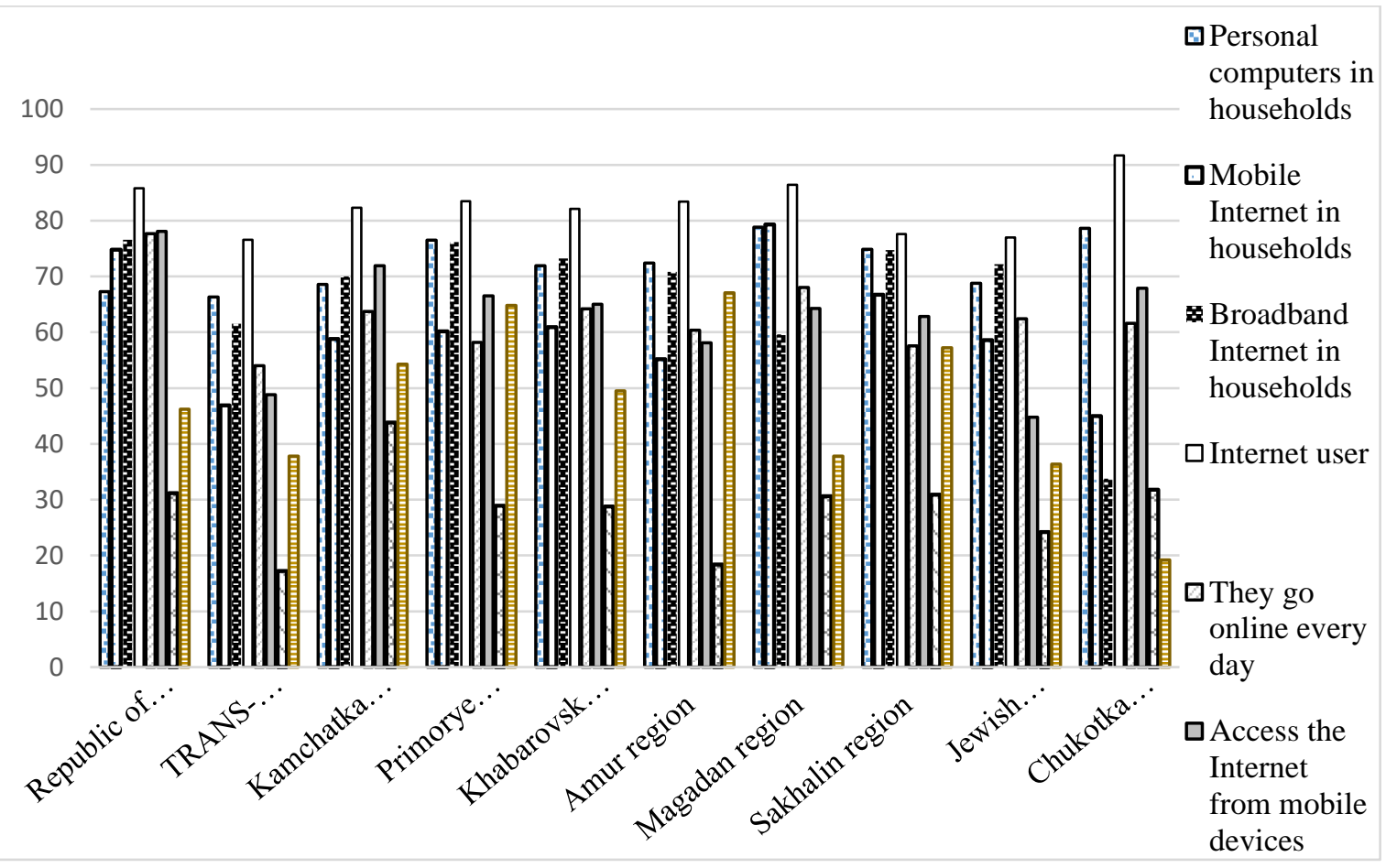

Figure 1 Indicators of information and communication (IIC) technologies of the population of the Far Eastern Federal District in 2017 (as a percentage)

a The diagram is compiled by the authors on the basis of official data of the Federal state statistics servic

In terms of the use of information and communication technologies, in General, the Far Eastern Federal District regions go to the average values, an important role is played by the remoteness of the Far Eastern Federal District from 
Eastern Federal District is given. Finally, the main conclusions and directions for further research are presented at the end of the paper. which is associated with the delivery of these goods in remote areas (i.e., poorly developed logistics network for the delivery of Internet shopping population). The use of public services on the Digital government portal reaches $47 \%$ in the Far Eastern Federal District, which, according to the authors, is due to insufficient coverage of public services that can be obtained by the population in electronic form, and MFC do not exist and operate in all hard-to-reach areas of the Far Eastern Federal District (or their work is not profitable).

At the same time, the Far Eastern Federal District needs to improve the education system, which should provide the digital economy with competent personnel, taking into account the transformation of the labor market, as well as creating a system of motivation for the development of necessary competencies and participation of personnel in the development of the digital economy of the region.

At the same time, it should be noted a number of factors that affect the level of development of the digital economy in the Far Eastern Federal District. First of all, this is the level of development of information communications, which is aimed at improving the activities of the regional project " Information infrastructure. Given the territorial extent of the Far Eastern Federal District and the inaccessibility of certain areas, new technological solutions and innovative developments are needed to solve this problem. It is obvious that traditional solutions to the problem of developing information and communication systems for the Far Eastern Federal District will be expensive and difficult to implement. Additional funding (subsidies) is needed for the introduction of digital technologies in the areas of healthcare, education, social protection, state and municipal management, and the economy of the entire Far Eastern Federal District.

\subsection{Our contribution to the research}

Public statistics do not fully assess the goals of the national digital economy project, so it is difficult to assess the degree and quality of its implementation. Based on the indicators calculated above, the authors tried to fix a quantitative value, a kind of basic level, from which the implementation of the national program "Digital economy" began.

\subsection{Paper Structure}

The rest of the article is organized as follows. Section 2 presents preliminary conclusions and goals regarding the implementation of the national program " Digital economy", which include preliminary research results based on the above analysis and evaluation of state statistics. An assessment of the current legislation on the development of the digital economy in Russia and the Far

\section{PRELIMINARY ASSESSMENT OF DIGITALIZATION DEVELOPMENT INDICATORS IN THE FAR EASTERN FEDERAL DISTRICT BASED ON ROSSTAT DATA}

Statistical data processed by Rosstat in the period from 2010 to 2018 do not directly reflect the values of the target indicators of the projects "Digital technologies", "Digital public administration", etc., included in the passport of the national project "national program "Digital economy of the Russian Federation". At best, individual statistical measurements indirectly reflect the dynamics of individual targets of the national program "Digital economy of the Russian Federation". State statistics do not fully assess the goals of the national digital economy project, so it is difficult to assess the degree and quality of its implementation. Based on the indicators calculated above, the authors tried to fix a quantitative value, a kind of basic level, from which the implementation of the national program "Digital economy" began. I. e. with what initial values of using global networks, specialized programs for managing economic processes, and the degree of information security, households, businesses, and government agencies entered the implementation of the national program "Digital economy" in 2018. how much has the digital infrastructure of the economy improved, and society's readiness to use the digital environment in comparison with 2010 and 2013? These measurements are necessary for further studies of the phased implementation of this national project. All calculations were made based on the national average. Thus, it should be borne in mind that the extent of the territory of the Russian Federation is big, there is uneven distribution of development of individual counties in the sphere of digital economy and especially remote areas, such as the North and the far East, characterized by harsh climatic conditions, low density living in the area of the population, a weak infrastructure for network communications (particularly in remote areas), etc. In this context, another direction is being formed to assess the implementation and development of the digital economy in the country, or rather in such remote areas as the Far Eastern Federal District - the psychological and social readiness of the population to transition to the digital economy. 


\subsection{Directions of actions of the Executive power to solve the problems of integration of the "Digital economy" in the socio- economic sphere of the region}

In General, in order to eliminate obstacles in the implementation of the national project "national program "Digital economy", it is necessary to direct the efforts of the Executive power to solve problems:

1) coordinated work of the Executive power and educational institutions to develop new professional standards and educational programs for training the required specialists in the field of digital economy, updating the material base and training tools for the implementation of educational programs in this area;

2) development of programs for retraining and advanced training of personnel in the digital economy;

3 ) correction of the system of indicators for evaluating the state statistics services for a more accurate assessment of the level of implementation of the targets of the national digital economy project, since it is difficult to assess the degree and quality of its implementation based on current values;

4) a separate approach to the implementation of the national digital economy program in remote areas, such as the Far Eastern Federal District - a review of the level of funding for the far Eastern region in terms of the development of the digital economy on its territory.

\subsection{Results of the study}

1) In terms of the use of information and communication technologies, in General, the Far Eastern Federal District regions go to the average values, an important role is played by the remoteness of the Far Eastern Federal District from the Western areas of Russia, on the one hand the use of the Internet and home computers in households the average reaches $70 \%$, while online purchases represent $28.6 \%$, which is associated with the delivery of these goods in remote areas (i.e., poorly developed logistics network for the delivery of Internet shopping population). The use of public services on the Digital government portal reaches $47 \%$ in the Far Eastern Federal District, which, according to the authors, is due to insufficient coverage of public services that can be obtained by the population in electronic form, and MFC do not exist and operate in all hard-to-reach areas of the Far Eastern Federal District (or their work is not profitable).

2) At the same time, the Far Eastern Federal District needs to improve the education system, which should provide the digital economy with competent personnel, taking into account the transformation of the labor market, as well as creating a system of motivation for the development of necessary competencies and participation of personnel in the development of the digital economy of the region.
3) At the same time, it should be noted a number of factors that affect the level of development of the digital economy in the Far Eastern Federal District. First of all, this is the level of development of information communications, which is aimed at improving the activities of the regional project "Information infrastructure. Given the territorial extent of the Far Eastern Federal District and the inaccessibility of certain areas, new technological solutions and innovative developments are needed to solve this problem. It is obvious that traditional solutions to the problem of developing information and communication systems for the Far Eastern Federal District will be expensive and difficult to implement. Additional funding (subsidies) is needed for the introduction of digital technologies in the areas of healthcare, education, social protection, state and municipal management, and the economy of the entire Far Eastern Federal District

\section{ACKNOWLEDGMENT}

This work was supported by Far-East Institute of management, branch of the Russian Presidential Academy of National Economy and Public Administration (hereinafter RANEPA), Department of mathematical methods and information technologies, Khabarovsk 680000, Russia.

\section{REFERENCES}

[1] Passport of the national project "national program" Digital economy of the Russian Federation "(approved by the Presidium of the Council under the President of the Russian Federation for strategic development and national projects, Protocol of 04.06.2019 N 7)

[Electronic resource] / access Mode:

http://www.consultant.ru/cons/cgi/online.cgi?rnd=85CE C0039601A72A759A75A664883D68\&req $=$ doc \&base $=$ LAW $\& n=328854 \&$ REFFIELD $=3 \&$ REFDST $=1 \&$ REFD $\mathrm{OC}=319432 \&$ REFBASE $=$ LAW \&stat $=$ refcode $\% 3 \mathrm{D} 166$ 10\%3Bindex\%3D3\#5s8jh6otrww. access date: 08.09.2019. Free.

[2] Decree of the President of the Russian Federation of 07.05.2018 №204 "On national goals and strategic objectives of the development of the Russian Federation for the period up to 2024" [Electronic resource] / access Mode: http://www.kremlin.ru/acts/bank/43027/page/2. Free

[3] Zubarev A. E. Digital economy as a form of manifestation of regularities in the development of the new economy. Vestnik TOGU. 2017. No. 4 (47). Pp. $177-184$.

[4] Zhadan I. E. Social risks in the digital economy, Humanitarian scientific journal. 2018. \#1-1. Pp. 20-26. 
[10] The official website of "Levada-center".

[5] Sudarushkina I. V., Stefanova N. A. Digital economy, ANI: Economics and management. 2017. No. 1 (18). Pp. 182-184.

[6] Chernova V. Yu. Russian consumer in the digital economy / / Discussion. 2019. No. 2 (93). Pp. 38-41.

[7] Shvab K. the Fourth industrial revolution / K. Shvab - "Eksmo", 2016 - (Top Business Awards) [Electronic resource] / access Mode: http://ncrao.rsvpu.ru/sites/default/files/library/k._shvab chetvertaya_promyshlennaya_revolyuciya_2016.pdf

[8] Information society: main characteristics of the subjects of the Russian Federation: statistical collection / M. A. Sabelnikova, G. I. Abdrakhmanova, L. M.

Gokhberg, O. Yu. Dudorova et al.; Rosstat; national Statistical service. research. Higher school of

Economics. Moscow: HIGHER school of Economics, 2018. - $216 \mathrm{p}$.

[9] The official website of "Levada-center". [Electronic resource] / access Mode: https://www.levada.ru/
[Electronic resource] / access Mode: https://www.levada.ru/2019/11/11/2-rossiyan-polnostyuotkazalis-ot-nalichnyh/ access date: 11.11.2019. Free

[11] The official website of "Levada-center". [Electronic resource] / access Mode: https://www.levada.ru/2019/04/15/otsenka-biznesomvvedeniya-markirovki-tovarov-v-rossii/

[12] The official website of "Levada-center". [Electronic resource] / access Mode: https://www.levada.ru/2018/11/13/polzovanieinternetom-2/ access date: 11.11.2019. Free

[13] Digital economy-national projects-Khabarovsk territory. [Electronic resource] / access Mode: https://www.khabkrai.ru/khabarovskkrai/Proekty/175469. access date: 08.09.2019. Free

[14] Official portal "Ministry of digital development, communications and mass communications of the Russian Federation" [Electronic resource] / access Mode: https://digital.gov.ru/ru/pages/statistika-otrasli/ 